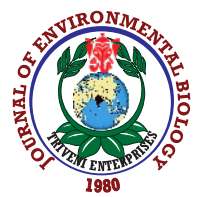

\title{
Efficacy of foliar application of nutrients on yield and quality of guava
}

\author{
S. Poojan ${ }^{1,2}$, D. Pandey ${ }^{2}$, A.K. Trivedi ${ }^{2 *}$, A.K. Pandey ${ }^{3}$ and M. Pandey ${ }^{1}$ \\ 'Department of Horticulture, Babasaheb Bhimrao Ambedkar University, Lucknow - 226025 , India \\ ${ }^{2}$ ICAR- Central Institute for Subtropical Horticulture, Lucknow - 226 101, India \\ ${ }^{3}$ Department of Fruit and Fruit Technology, Bihar Agriculture University, Sabour- 813210 , India \\ *Corresponding Author Email : ajayakumartrivedi@gmail.com
}

Paper received: 23.11.2019 Revised received: 26.03.2020

Accepted: 01.04 .2020

\section{Abstract}

Aim: To assess the efficacy of foliar application of nutrients, i.e., calcium as calcium chloride and boron as borax on yield and quality of guava ( $P$ sidium guajava L.) CV. Lalit fruits.

Methodology: Nineteen -year- old uniform guava plants planted at $6 \times 6 \mathrm{~m}$ apart were selected for investigation. Foliar application of calcium chloride $\left(\mathrm{CaCl}_{2}\right)$ and borax $\left(\mathrm{Na}_{2}\left[\mathrm{~B}_{4} \mathrm{O}_{5}(\mathrm{OH})_{4}\right] \cdot 8 \mathrm{H}_{2} \mathrm{O}\right)$ was done as split dose application during first week of August and second week of September in the year 2017 and 2018. Nine treatments in toto viz., $\mathrm{T}_{0}$ (Control), $\mathrm{T}_{1}$ (Calcium chloride $0.1 \%), \mathrm{T}_{2}$ (Calcium chloride $\left.0.2 \%\right), \mathrm{T}_{3}($ Borax, $0.1 \%), \mathrm{T}_{4}$ (Borax 0.2\%), $\mathrm{T}_{5}$ (Calcium chloride 0.1\% + Borax 0.1\%), $\mathrm{T}_{6}$ (Calcium chloride $0.1 \%+$ Borax $0.2 \%), T_{7}$ (Calcium chloride $0.2 \%$ + Borax $0.1 \%$ ), $\mathrm{T}_{8}$ (Calcium chloride $0.2 \%+$ Borax $0.2 \%$ ) were applied as foliar feeding. Effect of treatments was recorded on fruit length, fruit width, fruit volume, fruit yield ( $\mathrm{kg} \mathrm{tree}^{-1}$ ), fruit specific gravity, total soluble solids, acidity, ascorbic acid, total sugar, reducing sugar and non-reducing sugar content of fruit.

Results: Foliar application of calcium chloride @ $0.2 \%$ along with borax $@ 0.1 \%$ was the best treatment combination among the all treatments for improving fruit yield (i.e., from $44.333 \mathrm{~kg}$ tree ${ }^{-1}$ to $61.170 \mathrm{~kg}^{-1} \mathrm{tree}^{-1}$ ) and quality of guava fruits (viz., TSS $7.613-11.670{ }^{\circ} \mathrm{Brix}$, ascorbic acid

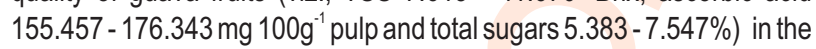
environmental conditions akin to environmental conditions of Horticultural Research Farm of Babasaheb Bhimrao Ambedkar University, Lucknow (India).

Interpretation: Judicious application of calcium and boron as foliar spray might ameliorate adverse effects of soil and environmental factors and improve production and quality of guava fruits.

Key words: Borax, Calcium chloride, Foliar application, Guava, Nutrients

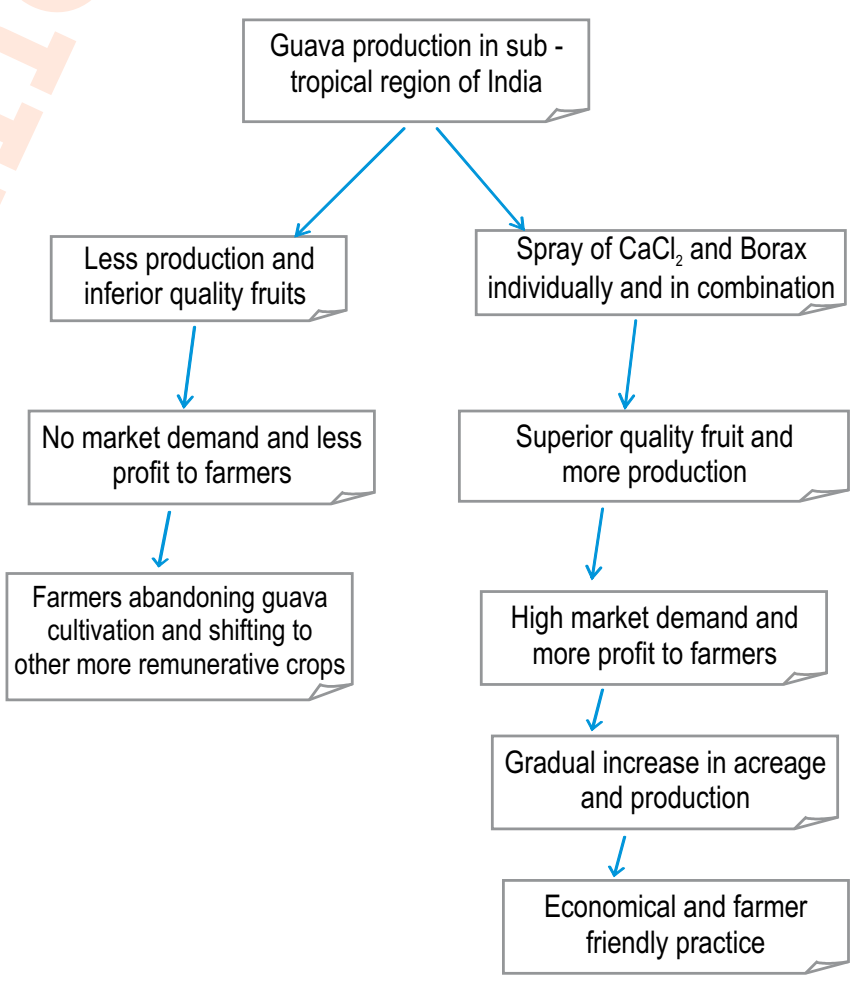

How to cite : Poojan, S., D. Pandey, A.K. Trivedi, A.K. Pandey and M. Pandey: Efficacy of foliar application of nutrients on yield and quality of guava. J. Environ. Biol., 41, 1061-1067 (2020). 


\section{Introduction}

Guava (Psidium guajava L.) popularly known as "Apple of Tropics" and "Super fruit" belong to the family myrtaceae. It is a tropical, hardy, prolific bearer fruit tree cultivated in most of the tropical and subtropical regions round the world (Samson, 1986). It found favour with the fruit growers due to its wide adaptability and higher return per unit area. Guava is widely grown all over the country in the kitchen garden, near the well and tube well premises and also on commercial scale (Bal, 2004). It is native to Tropical America and was introduced in India during early $17^{\text {th }}$ century (Hayes, 1957). It has become popular because of its availability almost throughout the year. It occupies an important place immediately after mango, banana and citrus (Malleswari, 1996). Its production is reported in 58 countries (Knight, 1980). Guava is successfully cultivated in a wide range of environmental and edaphic conditions owing to its tolerance to moisture stress and soil salinity as compared to most of the warm climate fruit plants. It is more resistant to drought than most of the fruit trees and can withstands summer temperature as high as $46^{\circ} \mathrm{C}$ (Taiwo, 2005). The crop is adaptable to diverse soil and climate conditions (Annon, 2005).

The genus Psidium has about 150 species (Hayes, 1957). All cultivar varieties belong to $P$. guajava $L$. and are either diploid $(2 n=2 x=22)$ or triploids $(2 n=3 x=33)$ (Atchinson et al., 1947). De Candolle (1904), Linnaeus divided P. guajava into two subspecies and termed them pomiferum and pyriferum. Guavas are rich in dietary fibre and vitamin $\mathrm{C}$, with moderate levels of folic acid. It has generally broad, low-calorie profile of essential nutrients. A single guava ( $P$. guajava) fruit contains about four times the amount of Vitamin $\mathrm{C}$ as an orange. A guava fruit contains $80-82 \%$ water, $0.71 \%$ protein, $0.5 \%$ fat, $11-13 \%$ carbohydrate and $2.4 \%$ Vitamin C. Moreover, red guava (100g) contains $80.8 \mathrm{~g}$ water; $68 \mathrm{kcal}$ energy; $2.55 \mathrm{~g}$ protein; $0.95 \mathrm{~g}$ fat, $14.32 \mathrm{~g}$ carbohydrate; 5.4 total dietary fiber; $8.92 \mathrm{~g}$ total sugar; 25 $\mu \mathrm{g}$ total carotene, $1.39 \mathrm{~g}$ ash; $374 \mu \mathrm{g} \quad \beta$-carotene; $5.204 \mu \mathrm{g}$ lycopene (Chen et al., 2007) and 87mg Vitamin C (Mahmud, 2009). The fruit is a rich source of Vitamin $A$, and flavonoids like beta-carotene, lycopene, lutein and cryptoxanthin and soluble dietary fibre ( $5.4 \mathrm{~g}$ per $100 \mathrm{~g}$ of fruit), which makes it a good bulk laxative. Guava can be consumed fresh or can be processed into juice, nectar, pulp, jam, jelly, and slices in syrup, fruit bar or dehydrated products, as well as can be used as an additive to other fruitjuices or pulps (Leite et al., 2006).

The effects of macro and micronutrient deficiencies are visible in terms of stunted growth, low yield and dieback and even may result in plant death. Moreover, foliar application of these nutrients may produce better results. Foliar fertilization of nutrients has advantage of low application rates, uniform distribution of nutrients and quick response to applied nutrients. Application of nutrients through foliage can be 10 to 20 times more effective than soil application (Zaman and Schumann,
2006). Micronutrients are key elements in plants growth and development. These elements play an important role in various enzymatic activities and synthesis. Their acute deficiencies some time pose the problem of incurable nature (Kumar, 2002). Micronutrients also help in the uptake of major nutrients and play an active role in the plant metabolism process starting from cell wall development to respiration, photosynthesis, chlorophyll formation, enzyme activity hormone synthesis, nitrogen fixation and reduction (Das, 2003). The fruit quality of rainy season guava is poor which can be improved by better nutrient schedule through foliar application. Foliar spray of borax and calcium chloride not only improves the size but also enhance the qualitative traits of the fruits. Micronutrient such as boron is a constituent of cell membrane and essential for cell division and ovule development, pollen tube growth and fruit set. Calcium salts such as lactate, chloride and nitrate (0.5-3.5\%) have shown promising results in shelf life extension and quality retention in guava (Hiwale and Singh, 2003; Selvan and Bal, 2005; Mahajan et al., 2011; Barche et al., 2015). Although, importance of these elements in improving the physiological activities of plants has been realized but standardization of dose, time and mode of application in a particular crop and agroclimatic conditions is required. Therefore, the present study was undertaken to evaluate the effects of calcium and boron, individually and in combination for improving yield and quality of guava fruits.

\section{Materials and Methods}

The experiment was conducted during the year 2017 and 2018 at Horticultural Research Farm of Babasaheb Bhimrao Ambedkar University, Lucknow (India). Experimental site has sub-tropical climate. Soil of orchard is clay loam which is well drained and well aerated. The soil texture was quite loose suited for the development of plant root system.

Nineteen-year-old uniform guava plants planted $6 \times 6 \mathrm{~m}$ apart were selected for investigation. In fruit science research, availability of desired number of plants of a particular species and cultivar at one location is a limitation. In case of guava, fruiting age starts three years after planting and these plants remain productive up to age $>40$ years. In the research farm of the University, available plants of guava were 19-year-old, hence, they were selected for study. Nutrient application and other orchard management practices were followed as per recommended package of practices for guava. Nine treatments in toto viz., $\mathrm{T}_{0}$ (Control), $\mathrm{T}_{1}$ (Calcium chloride 0.1\%), $\mathrm{T}_{2}$ (Calcium chloride 0.2\%), $\mathrm{T}_{3}$ (Borax 0.1\%), $\mathrm{T}_{4}$ (Borax 0.2\%), $\mathrm{T}_{5}$ (Calcium chloride $0.1 \%+$ Borax 0.1\%), $\mathrm{T}_{6}$ (Calcium chloride $0.1 \%+$ Borax $0.2 \%), \mathrm{T}_{7}$ (Calcium chloride $0.2 \%+$ Borax 0.1\%), $\mathrm{T}_{8}$ (Calcium chloride $0.2 \%+$ Borax $0.2 \%$ ) were sprayed (foliar feeding) during first week of August (fruit initiation) and second week of September (fruit development) during 2017-18.The experiment was conducted in randomized block design (RBD) with three replications. 
Fruit length and breadth of 10 sample fruits from each treatment was measured with the help of digital Vernier Calliper and expressed in cenitmeter (cm).Weight of above sampled fruits was taken on physical balance and average was expressed as gram per fruit.Volume of fruit was measured with the help of volumetric flask and expressed in millilitre $(\mathrm{ml})$. The fruit weight of each treatment was recorded and total fruits yield per ha was calculated at the final harvesting and expressed as quintal per hectare $\left(q\right.$ ha $\left.^{-1}\right)$.

The specific gravity of fruits was determined by dividing the weight of the fruits in air by the volume of fruits as obtained by water displacement method (Gustafson, 1926).

Bio-chemical parameters viz.; total soluble solids were estimated at ambient temperature by digital hand refractometer. Titrable acidity was calculated by titrating the fruit pulp extract with $0.1 \mathrm{~N} \mathrm{NaOH}$ using phenolphthalein indicator (Ranganna, 2010). Ascorbic acid, total sugar, reducing sugar, and non-reducing sugar content in fruit sample were estimated by the method described by Ranganna (2010). The data so obtained were analysed statistically as per method described by Gomez (1984) using OPSTAT (http://14.139.232.166/opstat/) software.

\section{Results and Discussion}

Significant improvement in the fruit yield was found in treated plants as compared to control the maximum fruit yield (61.17 kg per tree) was recorded in $T_{7}$ followed by $T_{8}$. This seems to be due to enhanced availability of calcium and boron for different plant processes. Moreover, boron might be involved in mobilizing other nutrients. As a consequence of boron nutritional status, changes in plant hormones were found (Eggert and Nicolaus, 2017), hence, boron supplementation may affect hormonal levels which in turn create conducive conditions for plant growth, development and yield. It is believed that boron brings about inactivation of superfluous growth hormone by formation of complex compounds. Suboptimal nutrient supply is a key factor regulating plant growth and development, and in most cases this includes alterations in plant hormone homeostasis (Eggert and Nicolaus, 2017). Furthermore, foliar application of nutrients was found to improve size (length, width) and weight of fruit, which ultimately increased the fruit yield. Similarly, calcium is involved in the regulatory mechanisms that plants activate to adjust with the adverse environmental conditions of drought (Upadhyaya et al., 2011) heat (Wang et al., 2009), cold (Zhou and Guo, 2009), salt (Zehra et al., 2012) and heavy metals (Siddiqui et al., 2011). Calcium chloride promotes growth hormones, starch formation, seed maturation and weight of fruit. Pre-harvest spray of calcium and boron was found to improve fruit size and quality of guava (Kumar et al., 2010; Awasthi and Lal, 2009).

Foliar spray of different treatments proved beneficial in increasing the length, width, weight and volume of fruit as compared to control (Table 1). The maximum length $(7.89 \mathrm{~cm})$, width $(7.84 \mathrm{~cm})$, weight $(135.67 \mathrm{~g})$ and volume $(120.63 \mathrm{ml})$ of fruit was recorded in $T_{7}$ which was closely followed by $T_{8}$. The minimum length, width, weight and volume of fruit was recorded in control plants. This increase in length and width of guava fruit might be due to the fact that mineral nutrients (calcium and boron) have indirect role in hastening the process of cell division and cell elongation due to which size, weight and volume improves (Hepler, 2005). Calcium ions are involved in nearly all aspects of plant development (Bothwell and Ng, 2005). Moreover, increased fruit weight, size (length and width) and volume of guava fruit by borax spray has been reported earlier (Singh et al., 2004; Pal et al., 2008).

The maximum total soluble solids $\left(11.67^{\circ}\right.$ Brix) were recorded in $T_{7}$ followed by $T_{8}$. Calcium and boron helps in transmembrane sugar transport which might be possible reason for increase in the total soluble solids in calcium and boron treated plants (Hepler, 2005). In addition, boron is especially required more in meristematic cells than in mature tissues (Rerkasem, 1996). It is essentially required for actively growing regions of plants, such as root tips, new leaf and bud development. Several impairments such as sugar transport, cell wall synthesis,

Table 1 : Effect of foliar application of nutrients on different traits of fruit and yield of guava cv. Lalit

\begin{tabular}{|c|c|c|c|c|c|c|c|}
\hline Treatments & $\begin{array}{l}\text { Fruit length } \\
\text { (cm) }\end{array}$ & $\begin{array}{l}\text { Fruit width } \\
\text { (cm) }\end{array}$ & $\begin{array}{l}\text { Fruit weight } \\
\text { (g) }\end{array}$ & $\begin{array}{l}\text { Fruit } \\
\text { volume }\left(\mathrm{cm}^{3}\right)\end{array}$ & $\begin{array}{l}\text { Fruit yield } \\
\left(\mathrm{kg} \mathrm{tree}^{-1}\right)\end{array}$ & $\begin{array}{l}\text { Fruit yield } \\
\left(q \mathrm{ha}^{-1}\right)\end{array}$ & $\begin{array}{l}\text { Fruit specific } \\
\text { gravity }\end{array}$ \\
\hline $\mathrm{T}_{0}$ & 6.53 & 5.72 & 103.89 & 92.33 & 44.33 & 124.71 & 0.95 \\
\hline $\mathrm{T}_{1}$ & 7.29 & 6.59 & 111.58 & 105.63 & 50.07 & 138.65 & 1.06 \\
\hline $\mathrm{T}_{2}$ & 6.86 & 6.36 & 119.95 & 108.78 & 55.42 & 153.57 & 1.05 \\
\hline $\mathrm{T}_{3}$ & 7.47 & 6.15 & 108.48 & 103.57 & 48.63 & 134.82 & 1.13 \\
\hline $\mathrm{T}_{4}$ & 6.01 & 6.76 & 113.86 & 114.42 & 52.38 & 144.93 & 1.05 \\
\hline $\mathrm{T}_{5}$ & 7.73 & 6.21 & 111.29 & 110.76 & 53.61 & 149.67 & 1.15 \\
\hline $\mathrm{T}_{6}$ & 7.60 & 6.40 & 121.98 & 108.70 & 56.26 & 142.65 & 1.14 \\
\hline $\mathrm{T}_{7}$ & 7.90 & 7.85 & 135.67 & 120.63 & 61.17 & 167.61 & 1.17 \\
\hline $\mathrm{T}_{8}$ & 7.79 & 7.20 & 129.76 & 115.40 & 58.66 & 162.07 & 1.15 \\
\hline SEm \pm & 0.18 & 0.15 & 0.55 & 0.63 & 0.739 & 0.51 & 0.01 \\
\hline$C D_{0.05}$ & 0.55 & 0.41 & 1.662 & 1.913 & 2.234 & 1.56 & 0.031 \\
\hline
\end{tabular}


Table 2 : Effect of foliar application of nutrients on fruit quality of guava cv. Lalit

\begin{tabular}{lllllll}
\hline Treatments & TSS ('Brix) & Acidity (\%) & $\begin{array}{l}\text { Ascorbic acid } \\
\left(\mathbf{m g ~ 1 0 0 g}^{-1} \text { pulp) }\right.\end{array}$ & $\begin{array}{l}\text { Total sugar } \\
(\%)\end{array}$ & $\begin{array}{l}\text { Reducing sugar } \\
(\%)\end{array}$ & $\begin{array}{l}\text { Non-reducing } \\
\text { sugar }(\%)\end{array}$ \\
\hline $\mathrm{T}_{0}$ & 7.61 & 0.75 & 155.46 & 5.38 & 2.50 & 2.88 \\
$\mathrm{~T}_{1}$ & 8.88 & 0.67 & 161.48 & 6.23 & 3.55 & 2.68 \\
$\mathrm{~T}_{2}$ & 9.24 & 0.53 & 168.52 & 6.24 & 3.66 & 2.58 \\
$\mathrm{~T}_{3}$ & 7.78 & 0.56 & 161.23 & 6.38 & 3.60 & 2.78 \\
$\mathrm{~T}_{4}$ & 8.47 & 0.55 & 160.30 & 6.22 & 2.62 & 3.62 \\
$\mathrm{~T}_{5}$ & 9.30 & 0.54 & 156.19 & 6.39 & 3.62 & 2.76 \\
$\mathrm{~T}_{6}$ & 10.33 & 0.54 & 171.50 & 6.54 & 3.28 & 3.26 \\
$\mathrm{~T}_{7}$ & 11.67 & 0.46 & 176.34 & 7.55 & 3.87 & 3.68 \\
$\mathrm{~T}_{8}$ & 10.79 & 0.52 & 174.75 & 6.72 & 3.73 & 2.99 \\
$\mathrm{SEm}_{ \pm}$ & 0.24 & 0.01 & 1.23 & 0.16 & 0.12 & 0.12 \\
$\mathrm{CD}_{0.05}$ & 0.735 & 0.04 & 3.73 & 0.50 & 0.36 & 0.37 \\
\hline
\end{tabular}

lignification, cell wall structure, carbohydrate metabolism, RNA metabolism, respiration, indole acetic acid (IAA) metabolism, phenol metabolism, and membrane integrity have been reported due to inadequate boron availability (Pollard et al., 1977). Hence, improvement in fruit quality traits in treated plants might be due to involvement of boron in these processes. During fruit maturation and harvesting stage, the concentration of acidity in guava fruit was also affected by changes in sugars and other compounds due to increasing levels of nutrients in plant parts, which might be beneficial for improving the quality of fruit by reducing the acidity per cent. Awasthi and Lal (2009) and Singh et al. (2004) found that application of calcium and boron in guava during fruit development stage improves fruit size and quality.

Acidity of guava fruit significantly decreased under different treatments (Table 2). Acidity was maximum (0.75\%) in control $\left(T_{0}\right)$ whereas in treated plants it decreased which might be due to early ripening induced by treatments. Degradation of acid might have occurred during ripening. It also appears that total soluble solids increased at the expense of acidity in these fruits. Under the influence of borax and calcium chloride, acid might have been rapidly converted into sugars and their derivatives by the reaction involving the reversal of glycolytic pathway or be used in respiration or both. Decrease in acidity with simultaneous increase in sugar content of guava fruits by application of nutrients has been reported earlier by Ali et al. (1993), Pal et al., (2008) and Awasthi and Lal (2009) also.

Ascorbic acid (Vitamin C) is major and active chemical constituent of guava fruit responsible for its medicinal properties which is affected by genotype, nutritional status of plant, soil and temperature. The foliar spray of calcium chloride and borax has been found to play an important role in improving the ascorbic acid content of guava fruits. The maximum ascorbic acid (176.34 $\mathrm{mg} 100 \mathrm{~g}^{-1}$ pulp) was recorded in $\mathrm{T}_{7}$ plants followed by $174.75 \mathrm{mg}$

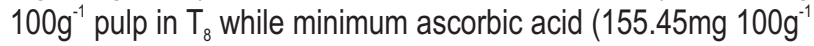
pulp) was recorded in control $\left(T_{0}\right)$. This seems to be due to the role

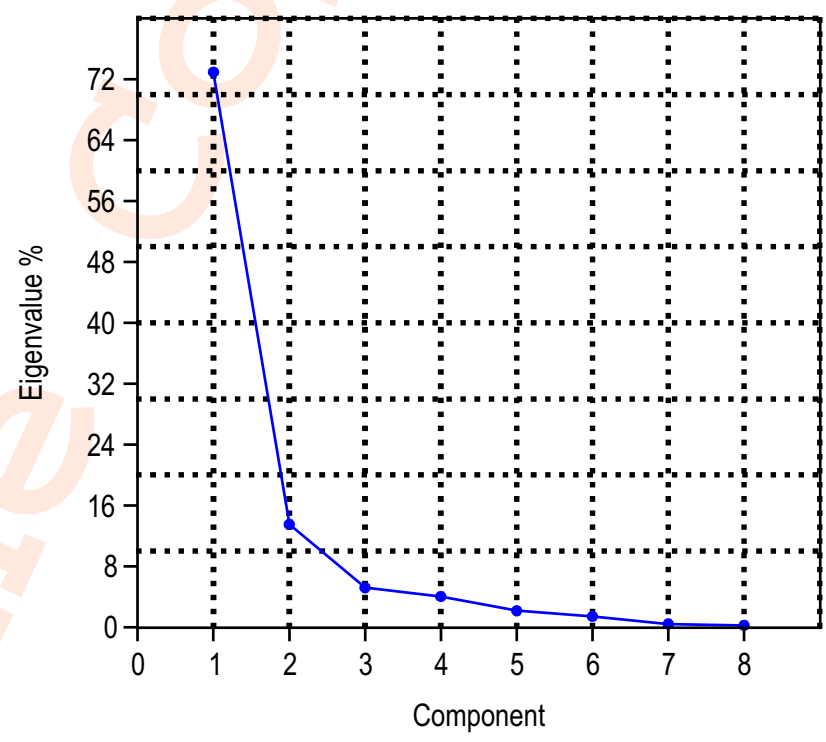

Fig. 1 : Scree plot of principal components.

of boron to activate the synthesis of ascorbic acid (Jain et al., 1985). Rajput and Chand (1976) found increase in total soluble solids, total sugars, vitamin $C$ and decrease in fruit acidity of guava by pre-blossom application of boron and zinc. Increase in sugar (reducing and non reducing) and ascorbic acid content of guava due to foliar application of boron and zinc was also reported by Trivedi et al. (2012). In addition, maximum reducing sugar $(3.87 \%)$, non-reducing sugar $(3.86 \%)$ and total sugars (7.54\%) were recorded in $\mathrm{T}_{7}$ followed by $\mathrm{T}_{8}$, while it was minimum in control $\left(\mathrm{T}_{0}\right)$. Awasthi and Lal (2009) studied the effect of calcium, boron and zinc application as foliar spray on yield and quality of guava fruits and found improvement in yield and sugar content. Recently, Sachin et al. (2019) reported increase in fruit size and yield of guava by foliar application of boron, zinc and copper. Similarly, Pippal et al. (2019) also reported increase in fruit size and yield of guava due to foliar spray of micronutrients (boron, zinc and magnesium). These reports are in close 


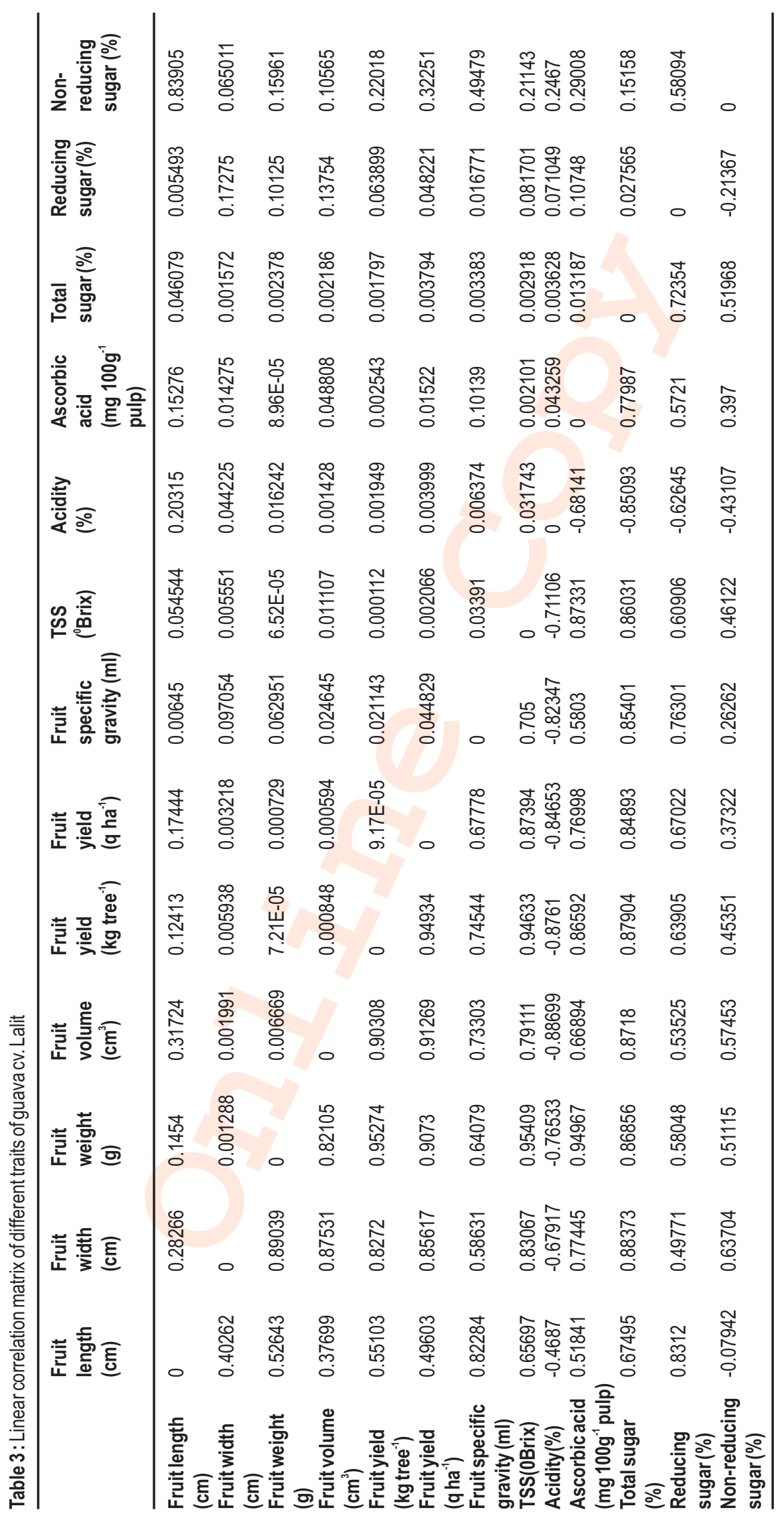

- Journal of Environmental Biology, September 2020 • 
Table 4 : Principal components, Eigen value and \% variance

\begin{tabular}{lll}
\hline Principal component & Eigen Value & \% Variance \\
\hline 1 & 404.11 & 90.663 \\
2 & 30.80 & 6.9101 \\
3 & 7.77 & 1.7436 \\
4 & 1.44 & 0.3243 \\
5 & 1.15 & 0.25847 \\
6 & 0.39 & 0.087661 \\
7 & 0.04 & 0.0091917 \\
8 & 0.01 & 0.0039713 \\
\hline
\end{tabular}

conformity with the findings of present investigation. Hence, foliar application of nutrients seems to be an effective method of improving yield and quality of guava fruits. From the correlation matrix (Table 3), it is obvious that fruit length is closely correlated with non-reducing sugar, fruit width with fruit length and fruit weight with fruit width. Similarly, fruit volume is positively correlated with fruit width and fruit yield with fruit weight. From the scree plot of principal components (Fig.1), it is evident that only four principal components contribute considerably towards diversity. Cumulative variance due to four principal components was $99.641 \%$ (Table 4). Fruit length, fruit width, fruit weight and fruit volume are four main traits which show variation in treatments effects.

The findings of the present study indicate that judicious application of calcium and boron as foliar spray might ameliorate adverse effects of soil and environmental factors and improve production and quality of guava fruits. Hence, studies on nutritional aspects of guava might have long lasting impact on guava production.

\section{Acknowledgment}

First author is thankful to Prof. R. B. Ram for help in planning and execution of the experiment and providing all the necessary facility for the experiment.

\section{Refrences}

Ali, W., R.A. Pathak and A.L. Yadav: Effect of foliar application of nutrients on guava (Psidium guajava L.) cv. Allahabad Safeda. Prog. Hort., 23, 14-21 (1993).

Annon: Production of citrus fruits. Proceedings of International Society of Citriculture, 8, 32-26 (2005).

Atchinson, E.: Chromosome number in thrmyrtaceae. Amer. J. Bot., 34, 159-164 (1947).

Awasthi, P. and S. Lal: Effect of calcium, boron and zinc foliar sprays on the yield and quality of guava (Psidium guajava). Pantnagar $\mathrm{J}$. Res., 7, 223-225 (2009).

Bal, J.S. and G.S. Dhaliwal: Distribution and quality characteristics of graded guava fruits. Haryana J. Hort. Sci., 33, 53-54 (2004).

Barche, S., R. Nair and K.S. Kirad: Effect of wax emulsion and packaging material in combination with calcium salts on the shelf life of guava (Psidium guajava L.) cv. Allahabad Safeda, at room temperature. The Ecoscan, Special Issue, VIII, 273-276 (2015).
Bothwell, J.H. and C.K. Ng: The evolution of $\mathrm{Ca}_{2}^{+}$signalling in photosynthetic eukaryotes. New Phytol., 166, 21-38 (2005).

Chen, H., Sheu M, Lin. and C. Wu: Nutritional composition and volatile compounds in guava. Fresh Procedure, 1, 132-139 (2007).

Das, D.K.: Micronutrients: Their behaviors in soils and plants. $2^{\text {nd }}$ Edn., Kalyani Publication, Ludhiana, pp. 1-2 (2003).

De, Candolle, A.P.: Origin of cultivated plants. Kegal Paul, London (1904).

Eggert, K. and V.W. Nicolaus: Response of the plant hormone network to boron deficiency. New Phytol., 216, 868-881 (2017).

Gomez, K.A. and A.A. Gomez: Statistical Procedure for Agricultural Research. $2^{\text {nd }}$ Edn., John Wiley and Sons Inc., New York (1984).

Gustafson P.G.: Growth studies of fruits. Plant Pathology, 1, 265-72 (1926).

Hayes, W.B.: Fruit growing in India. $3^{\text {rd }}$ Edn., Kitabistan Allahabad, pp. 283-299 (1957).

Hepler, P.K.: Calcium: A central regulator of plant growth and development. The Plant Cell, 17, 2142-2155 (2005).

Hiwale, S.S. and S.P. Singh: Prolonging shelf life of guava (Psidium guajava L.). Indian J. Hort., 60, 1-9 (2003).

Jain, B.P., S.R. Das and S.K. Verma: Effect of growth substances and major elements on the synthesis of major chemical constituents of litchi (Litchichinensis). Haryana J. Hort. Sci., 14, 1-3 (1985).

Knight, R. Jr:. Origin and world importance of tropical and subtropical fruit crops. In: Tropical and Sub-Tropical Fruits: Composition, Properties and Uses (Eds.: S. Nagy and P. E. Shaw.). AVI Publishing Incorporated, Westport, Conn. U.S.A., pp. 1-120 (1980).

Kumar, P.: Managing micronutrient deficiency in ornamental crops. Indian Horticult., 46, 30-31 (2002).

Kumar, Y. and H.S. Rattanpal: Effect of pruning in guava planted at different spacing under Punjab conditions. Ind. J. Hort., 67, 11511(2010).

Leite, B.M.S.C., A.C. Tadiottib, D. Baldochi and O. M. M. F. Oliveira: Partial purification, heat stability and kinetic characterization of the pectinmethylesterase from Brazilian guava, Paluma cultivars. Food Chem., 94, 565-572 (2006).

Mahajan, B.V.C., B.S. Ghuman and K.B. Harsimrat: Effect of postharvest treatments of calcium chloride and gibberellic acid on storage behaviour and quality of guava fruits. J. Hort. Sci. Orname. Plants, 3, 38-42 (2011).

Mahmud, M.K.: Indonesia's Food Composition (in Bahasa Indonesia) edZulfianto NA (Jakarta: PTElex Media Komputindo) (2009).

Malleswari, M.N.: Mango processing in Andhra Pradesh, potential infrastructure and constraints. Ind. J. Agri. Mark.,10, 18-27 (1996).

Nutritiondata.com. "Nutrition facts for common guava". Retrieved August $17(2010)$. 
Pal, A., R.K. Pathak, K. Pal and S. Tejbir: Effect of foliar application of nutrients on yield and quality of guava (Psidiumguajava L.) fruits cv. Sardar. Prog. Res., 3, 89-90 (2008).

Pippal, R., R. Lekhi, A.K. Barholia, S. Rana and P. Rana: Response of guava to foliar spray of zinc, boron and magnesium on growth, development and yield. J. Pharmac. Phytochem., 2, 942-946 (2019).

Pollard, A.S., A.J. Parr and B.C. Loughman.: Boron in relation to membrane function in higher plants. J. Exp. Bot., 28, 831-841 (1977).

Rajput, C.B.S. and S. Chand: Effects of boron and zinc on the physicochemical composition of guava fruits (Psidium guajava L.). J. Natl. Agric. Soc. Ceylon., 13, 49-54 (1976).

Ranganna, S.: Manual for analysis of fruits and vegetable products. Tata Mc. Grow Hill Co.Pvt. Ltd., New Delhi (2010).

Rerkasem, B.: Boron and plant reproductive development. In: Sterility in Wheat in Sub-tropical Asia: Extent, Causes and Solutions. (Eds.: H.M. Rawson and K.D. Subedi). ACIAR Proc. No. 72, pp. 32-35 (1996)

Sachin Kumar, A., V. Kumar, S.K. Tripathi and M. Kumar: Effect of foliar application of micronutrient on physical quality parameters of guava (Psidium guajava L,) cv. Lalit. Annal. Hort., 12, 130-133 (2019).

Samson, J.A.: Tropical Fruits. $2^{\text {nd }}$ Edn., Tropical Agriculture Series, Longman Scientific \& Technical, Longman Inc., New York (1986).

Selvan, M.T. and J.S. Bal: Effect of post harvest chemical treatments on shelf life of guava during ambient storage. Haryana J. Hort. Sci., 34,33-35(2005).
Siddiqui, M.H., M.H. Al-Whaibi and M.O. Basalah: Interactive effect of calcium and gibberellin on nickel tolerance in relation to antioxidant systems in Triticum aestivum L. Protoplasma, 248, 503-511 (2011).

Singh, R., O.P. Chaturvedi and R. Singh: Effect of pre-harvest spray of zinc, boron and calcium on the physico-chemical quality of guava fruit (Psidium guajava L.). International Seminar on Recent Trend on $\mathrm{Hi}-$ Tech Hort. and P.H.T., Kanpur, 2004, p.204 (2004).

Taiwo, T.A.: Production of fruits, vegetables, grains legumes, root crops in Nigeria: Problems and prospects. University Press., Vol. 1, 9-20 (2005).

Trivedi, N., D. Singh, V. Bahadur, V.M. Prasad and J.P. Collis: Effect of foliar application of zinc and boron on yield and quality of guava (Psidium guajava L.). Hort. Flora Res. Spect., 1, 281-283 (2012).

Upadhyaya, H., S.K. Panda, B.K. Dutta: $\mathrm{CaCl}_{2}$ improves postdrought recovery potential in Camellia sinensis $(\mathrm{L}) \mathrm{O}$ Kuntze. Plant Cell Rep., 30, 495-503 (2011).

Wang, Y., Q.Y. Yu, X.X. Tang and L.L. Wang: Calcium pretreatment increases thermo tolerance of Laminaria japonica sporophytes. Prog. Nat. Sci., 19, 435-442 (2009).

Zaman, Q. and A.W. Schumann: Nutrient management zones for citrus based on variation in soil properties and tree performance. PrecisionAgri., 7, 45-63 (2006).

Zehra, A., B. Gul, R. Ansari and M.A. Khan: Role of calcium in alleviating effect of salinity on germination of Phragmites karka seeds. South Afr. J. Bot., 78, 122-128 (2012).

Zhou, B. and Z. Guo: Calcium is involved in the abscisic acid-induced ascorbate peroxidase, superoxide dismutase and chilling resistance in Stylosanthes guianensis. Biol. Plant, 53, 63-68 (2009). 